\title{
A list of bees from three locations in the Northern Rockies Ecoregion (NRE) of western Montana
}

\author{
Elizabeth G. Reese ${ }^{\ddagger}$, Laura A. Burkle, Casey M. Delphia ${ }^{\ddagger}$, Terry Griswold§ \\ ‡ Department of Ecology, Montana State University, Bozeman, United States of America \\ § USDA-ARS Pollinating Insects Research Unit, Logan, United States of America
}

Corresponding author: Elizabeth G. Reese (elizabeth.reese1@montana.edu)

Academic editor: Yasen Mutafchiev

Received: 02 Jun 2018 | Accepted: 16 Oct 2018 | Published: 30 Oct 2018

Citation: Reese E, Burkle L, Delphia C, Griswold T (2018) A list of bees from three locations in the Northern

Rockies Ecoregion (NRE) of western Montana. Biodiversity Data Journal 6: e27161.

https://doi.org/10.3897/BDJ.6.e27161

ZooBank: urn:Isid:zoobank.org:pub:B7C28523-AA61-4A11-BD57-A914F432996A

\section{Abstract}

\section{Background}

Wild bees that were collected in conjunction with a larger study are presented as a checklist of species for the Northern Rockies Ecoregion of Montana, USA. Over the course of four field seasons (2013-2016), 281 species and morphospecies in 32 genera and five families were collected using insect nets, and identified. This paper addresses the distinct lack of studies monitoring bee species in Montana and contributes to a basic understanding of fauna in the northern Rocky Mountains.

\section{New information}

With this study, the number of known bee species in Montana increases by at least six species, from 366 (Kuhlman and Burrows 2017) to 372. Though literature was not reviewed for all the species on this checklist, published records in Montana revealed no listings for Andrena saccata Viereck; Anthidiellum notatum robertsoni (Cockerell); Ashmeadiella 
meliloti (Cockerell); Ashmeadiella pronitens (Cockerell); Colletes lutzi lutzi Timberlake; and Dioxys productus (Cresson).

\section{Keywords}

Apoidea, wild bees, biodiversity, pollinator, Montana, Rocky Mountains, Northern Rockies Ecoregion

\section{Introduction}

Faunistic studies characterizing native pollinators are becoming more important for understanding patterns in local and regional biodiversity as species are threatened by habitat loss, climate change and other factors (Green et al. 2005, Lengyel et al. 2008, Losos et al. 2013). Studies documenting wild bee species are particularly critical because bees are the world's primary animal pollinators in most ecosystems (Neff and Simpson 1993, Winfree 2010) and are currently undergoing declines across different spatial scales (Koh et al. 2015), including globally (Council, Natural Resource 2007). Much taxonomic work has focused on regional bee fauna in the eastern United States and several states in the western U.S., however there remains a dearth of studies documenting wild bees in Montana (but see Dolan et al. 2017 and Kuhlman and Burrows 2017).

Here we present a list of bee species from three localities in the northern Rocky Mountains collected over the course of four years as part of a larger project investigating the effects of wildfire on plant-pollinator diversity (Burkle et al. 2015). This paper contributes to the regional list of wild bees in Montana and addresses the need for pollinator monitoring in the western U.S.

\section{Materials and methods}

\section{Study Region}

The Northern Rockies Ecoregion (NRE) encompasses $162,746 \mathrm{~km}^{2}$ of Idaho, western Montana and northeastern Washington, and is characterized by high, rugged mountain ranges consisting of montane, alpine and subalpine ecosystems (Taylor 2012). Dominant vegetation includes lodgepole pine (Pinus contorta), ponderosa pine (Pinus ponderosa), western larch (Larix occidentalis), and mixed conifer forests. Climate in the NRE is dry, with most precipitation occurring as snow, and with very cold winters and short summers (Table 1). We collected bee specimens from the following three localities within the NRE: near Glacier National Park in Flathead County, Absaroka-Beartooth Wilderness in Park County, and Helena National Forest in Lewis and Clark County (see Fig. 1). 
Table 1.

Characterization of three study localities in the northern Rocky Mountains of Montana, USA. Values for mean annual temperature, mean annual precipitation, and elevation represent the mean of unburned transects within a site (Western Regional Climate Center 2016).

\begin{tabular}{|l|l|l|l|}
\hline & Flathead Co. (Kalispell) & Lewis \& Clark Co. (Helena) & Park Co. (Livingston) \\
\hline coordinates (latitude, longitude) & $48.6,-114.3$ & $46.7,-111.7$ & $45.2,-110.4$ \\
\hline temperature $\left({ }^{\circ} \mathrm{C}\right)$ & -2.2 & 15.8 & -13 \\
\hline precipitation $(\mathrm{mm})$ & 684 & 351 & 632 \\
\hline elevation $(\mathrm{m})$ & 1312 & 1373 & 2248 \\
\hline
\end{tabular}

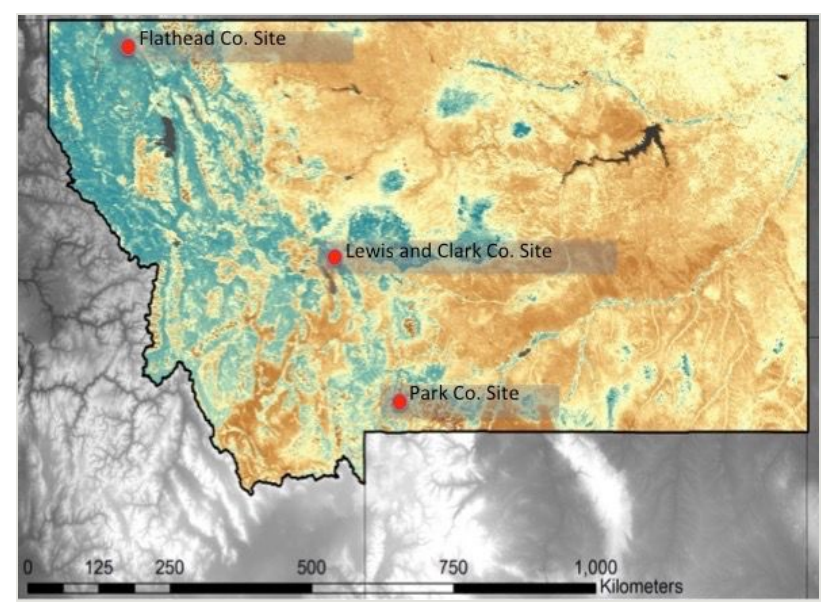

Figure 1. doi

Map of study localities in the Northern Rockies, Montana, USA.

\section{Collection Methods}

At each locality, we established nine $25 \mathrm{~m}$ diameter circular plots within each of four 15 hectare study blocks. Study blocks were located within previously determined wildfire perimeters. Within a block, plots were randomly stratified to meet research goals related to wildfire severity and to avoid spatial clumping of plots using a generalized random tessellation stratified (GRTS) survey design function in the R spsurvey package (Kincaid and Olsen 2011). Details of site selection and characteristics can be found in Burkle et al. 2015.

Bees were collected over four field seasons (2013-2016) beginning when plants started to bloom after snowmelt (late-May or June) and ending once most flower species had gone to seed (late-August). Collection dates for each species can be found in Supplementary Data Table 1 (Suppl. material 1). Each locality was sampled as often as possible per season, 
with sampling bouts being chiefly determined by weather. On every visit to a locality, we sampled each plot for 20 minutes. All insects that contacted the reproductive parts of flowers were collected with insect nets, pinned, and labeled with pertinent data, including plant species association. We visited the Lewis and Clark County locality five times in 2013, thirteen times in 2014, nine times in 2015 and seven times in 2016. At the Park County location, we visited two, eleven, nine, and six times in 2013, 2014, 2015 and 2016, respectively; and we visited the Flathead County location three times in 2013, and seven times in both 2014 and 2015.

\section{Species Identification}

Bee species were identified by Elizabeth Reese, Terry Griswold, Casey Delphia, Skyler Burrows, Harold Ikerd, Michael Orr, Jason Gibbs and Karen Wright. To make determinations to the lowest possible taxonomic level we used published keys or unpublished works where these were available (Table 2). When keys were not sufficient, or did not exist for this area, we designated morphospecies based on morphological characteristics. Morphospecies were labeled "F" for female or "M" for male and given unique numbers. In cases where two particular species were impossible to differentiate based on morphology, both species names were notated (i.e., females of Agapostemon texanus/angelicus). Specimens are deposited in the Montana State University Pollinator Health Center Collection located in the Burkle Community Ecology Lab at Montana State University in Bozeman, MT and the U.S. National Pollinating Insect Collection in Logan, UT.

Table 2.

List of published keys used for species identification.

\begin{tabular}{|l|l|l|}
\hline Family & Genus & Reference \\
\hline Andrenidae & Andrena & $\begin{array}{l}\text { Bouseman and LaBerge 1978, Donovan 1977, LaBerge 1969, LaBerge and Ribble } \\
1972, \text { LaBerge 1973, LaBerge 1977, LaBerge 1980, LaBerge 1985, LaBerge 1986, } \\
\text { LaBerge and Ribble 1975, Ribble 1974, Ribble 1968, Thorp 1969 }\end{array}$ \\
\hline & Panurginus & unpublished works \\
\hline Protandrena & Timberlake 1976 \\
\hline Anthophora & Ascher and Pickering 2016 \\
\hline Bombus & Koch et al. 2012, Thorp et al. 1983, Williams et al. 2014 \\
\hline Ceratina & Daly 1973 \\
\hline Diadasia & Sipes 2001 \\
\hline Epeolus & Brumley 1965 \\
\hline Eucera & Timberlake 1969 \\
\hline Melecta & Hurd and Linsley 1951 \\
\hline
\end{tabular}




\begin{tabular}{|c|c|c|}
\hline Family & Genus & Reference \\
\hline & Melissodes & LaBerge 1956a, LaBerge 1956b, LaBerge 1961 \\
\hline & Triepeolus & Rightmyer 2008 \\
\hline \multirow[t]{2}{*}{ Colletidae } & Colletes & Stephen 1954 \\
\hline & Hylaeus & Snelling 1966a, Snelling 1966b, Snelling 1970 \\
\hline \multirow[t]{4}{*}{ Halictidae } & Agapostemon & Roberts $1973 b$ \\
\hline & Dufourea & Dumesh and Sheffield 2012 \\
\hline & Halictus & Roberts 1973a \\
\hline & Lasioglossum & Gibbs 2010, McGinley 1986, McGinley 2003 \\
\hline \multirow[t]{12}{*}{ Megachilidae } & Anthidiellum & Hurd and Michener 1955 \\
\hline & Anthidium & Gonzalez and Griswold 2013 \\
\hline & Ashmeadiella & Hurd and Michener 1955 \\
\hline & Chelostoma & Michener 1938 \\
\hline & Coelioxys & Baker 1975, DeSilva 2012 \\
\hline & Dianthidium & Grigarick and Stange 1968 \\
\hline & Dioxys & Hurd 1958 \\
\hline & Heriades & Hurd and Michener 1955 \\
\hline & Hoplitis & Michener 1947 \\
\hline & Megachile & Sheffield et al. 2011 \\
\hline & Osmia & Sandhouse 1939, Rightmyer et al. 2010 \\
\hline & Stelis & unpublished works \\
\hline
\end{tabular}

\section{List of Bees}

\section{Colletes consors subsp. consors Cresson, 1868}

Notes: Collected from the Lewis and Clark County site (Table 1, Suppl. material 1)

\section{Colletes fulgidus Swenk, 1904}

Notes: Collected from the Lewis and Clark County and Park County sites(Table 1, Suppl. material 1) 
Colletes hyalinus subsp. hyalinus Provancher, 1888

Notes: Collected from the Park County site (Table 1, Suppl. material 1)

\section{Colletes kincaidii Cockerell, 1898}

Notes: Collected from the Lewis and Clark County site (Table 1, Suppl. material 1)

Colletes lutzi subsp. lutzi Timberlake, 1943

Notes: New species for Montana. Collected from the Lewis and Clark County and Park County sites (Table 1, Suppl. material 1)

\section{Colletes phaceliae Cockerell, 1906}

Notes: Collected from the Lewis and Clark County site (Table 1, Suppl. material 1)

\section{Hylaeus (Cephalylaeus) basalis (Smith, 1853)}

Notes: Collected from the Park County and Flathead County sites (Table 1, Suppl. material 1)

Hylaeus (Hylaeus) annulatus (Linnaeus, 1758)

Notes: Collected from the Lewis and Clark County, Park County and Flathead County sites (Table 1, Suppl. material 1)

\section{Hylaeus (Hylaeus) leptocephalus (Morawitz, 1871)}

Notes: Collected from the Lewis and Clark County site (Table 1, Suppl. material 1)

Hylaeus (Hylaeus) mesillae (Cockerell, 1896)

Notes: Collected from the Lewis and Clark County site (Table 1, Suppl. material 1)

Hylaeus (Hylaeus) rudbeckiae (Cockerell and Casad, 1895)

Notes: Collected from the Lewis and Clark County site (Table 1, Suppl. material 1)

Hylaeus (Hylaeus) verticalis (Cresson, 1869)

Notes: Collected from the Lewis and Clark County, Park County and Flathead County sites (Table 1, Suppl. material 1) 
Hylaeus (Paraprosopis) coloradensis (Cockerell, 1896)

Notes: Collected from the Lewis and Clark County and Park County sites (Table 1, Suppl. material 1)

Hylaeus (Paraprosopis) nevadensis (Cockerell, 1896)

Notes: Collected from the Lewis and Clark County site (Table 1, Suppl. material 1)

Hylaeus (Paraprosopis) wootoni (Cockerell, 1896)

Notes: Collected from the Lewis and Clark County and Park County sites (Table 1, Suppl. material 1)

Hylaeus (Prosopis) episcopalis (Cockerell, 1896)

Notes: Collected from the Lewis and Clark County and Park County sites (Table 1, Suppl. material 1)

Hylaeus (Prosopis) modestus Say, 1837

Notes: Collected from the Lewis and Clark County, Park County and Flathead County sites (Table 1, Suppl. material 1)

Andrena (Andrena) milwaukeensis Graenicher, 1903

Notes: Collected from the Lewis and Clark County and Park County sites (Table 1, Suppl. material 1)

Andrena (Andrena) saccata Viereck, 1904

Notes: New species for Montana. Collected from the Park County site (Table 1, Suppl. material 1)

Andrena (Andrena) thaspii Graenicher, 1903

Notes: Collected from the Lewis and Clark County, Park County and Flathead County sites (Table 1, Suppl. material 1)

Andrena (Andrena) topazana Cockerell, 1906

Notes: Collected from the Park County and Flathead County sites (Table 1, Suppl. material 1) 
Andrena (Andrena) sp. F1

Notes: Collected from the Lewis and Clark County site (Table 1, Suppl. material 1) Andrena (Cnemidandrena) surda Cockerell, 1910

Notes: Collected from the Lewis and Clark County site (Table 1, Suppl. material 1) Andrena (Diandrena) evoluta Linsley \& MacSwain, 1961

Notes: Collected from the Lewis and Clark County site (Table 1, Suppl. material 1) Andrena (Euandrena) lawrencei Viereck, \& Cockerell, 1914

Notes: Collected from the Lewis and Clark County site (Table 1, Suppl. material 1) Andrena (Euandrena) nigrocaerulea Cockerell, 1897

Notes: Collected from the Lewis and Clark County site (Table 1, Suppl. material 1) Andrena (Geissandrena) trevoris Cockerell, 1897

Notes: Collected from the Lewis and Clark County site (Table 1, Suppl. material 1) Andrena (Melandrena) nivalis Smith, 1853

Notes: Collected from the Lewis and Clark County and Flathead County sites (Table 1, Suppl. material 1)

Andrena (Melandrena) pertristis Cockerell, 1905

Notes: Collected from the Lewis and Clark County site (Table 1, Suppl. material 1) Andrena (Melandrena) transnigra Viereck, 1904

Notes: Collected from the Lewis and Clark County site (Table 1, Suppl. material 1) Andrena (Melandrena) vicina Smith, 1853

Notes: Collected from the Lewis and Clark County site (Table 1, Suppl. material 1) 
Andrena (Micrandrena) melanochroa Cockerell, 1898

Notes: Collected from the Lewis and Clark County and Park County sites (Table 1, Suppl. material 1)

Andrena (Micrandrena) microchlora Cockerell, 1922

Notes: Collected from the Lewis and Clark County site (Table 1, Suppl. material 1)

Andrena (Plastandrena) crataegi Robertson, 1893

Notes: Collected from the Lewis and Clark County and Park County sites (Table 1, Suppl. material 1)

Andrena (Plastandrena) prunorum Cockerell, 1896

Notes: Collected from the Lewis and Clark County and Park County sites (Table 1, Suppl. material 1)

Andrena (Scaphandrena) aff. shoshoni Ribble, 1974

Notes: Collected from the Lewis and Clark County site (Table 1, Suppl. material 1)

Andrena (Scaphandrena) scurra Viereck, 1904

Notes: Collected from the Lewis and Clark County site (Table 1, Suppl. material 1)

Andrena (Scaphandrena) walleyi Cockerell, 1932

Notes: Collected from the Lewis and Clark County site (Table 1, Suppl. material 1)

Andrena (Thysandrena) candida Smith, 1879

Notes: Collected from the Park County and Flathead County sites (Table 1, Suppl. material 1)

Andrena (Thysandrena) knuthiana Cockerell, 1901

Notes: Collected from the Park County and Flathead County sites (Table 1, Suppl. material 1)

Andrena (Thysandrena) medionitens Cockerell, 1902

Notes: Collected from the Lewis and Clark County site (Table 1, Suppl. material 1) 
Andrena (Thysandrena) vierecki Cockerell, 1904

Notes: Collected from the Park County site (Table 1, Suppl. material 1)

Andrena (Trachandrena) amphibola (Viereck, 1904)

Notes: Collected from the Lewis and Clark County, Park County and Flathead County sites (Table 1, Suppl. material 1)

Andrena (Trachandrena) cleodora (Viereck, 1904)

Notes: Collected from the Lewis and Clark County and Flathead County sites (Table 1, Suppl. material 1)

Andrena (Trachandrena) cupreotincta Cockerell, 1901

Notes: Collected from the Lewis and Clark County site (Table 1, Suppl. material 1)

Andrena (Trachandrena) miranda Smith, 1879

Notes: Collected from the Lewis and Clark County and Park County sites (Table 1, Suppl. material 1)

Andrena (Trachandrena) salicifloris Cockerell, 1897

Notes: Collected from the Lewis and Clark County and Park County sites (Table 1, Suppl. material 1)

Andrena (Trachandrena) sigmundi Cockerell, 1902

Notes: Collected from the Lewis and Clark County site (Table 1, Suppl. material 1)

Andrena sp. F7

Notes: Collected from the Lewis and Clark County and Park County sites (Table 1, Suppl. material 1)

Andrena sp. F8

Notes: Collected from the Lewis and Clark County and Flathead County sites (Table 1, Suppl. material 1) 
Andrena sp. F11

Notes: Collected from the Lewis and Clark County site (Table 1, Suppl. material 1)

Andrena sp. F12

Notes: Collected from the Lewis and Clark County site (Table 1, Suppl. material 1)

Andrena sp. F13

Notes: Collected from the Lewis and Clark County site (Table 1, Suppl. material 1)

Andrena sp. F14

Notes: Collected from the Lewis and Clark County site (Table 1, Suppl. material 1)

Andrena sp. F15

Notes: Collected from the Park County site (Table 1, Suppl. material 1)

Andrena sp. F16

Notes: Collected from the Lewis and Clark County site (Table 1, Suppl. material 1)

\section{Andrena sp. F17}

Notes: Collected from the Lewis and Clark County and Park County sites (Table 1, Suppl. material 1)

\section{Panurginus atriceps (Cresson, 1878)}

Notes: Collected from the Lewis and Clark County, Park County and Flathead County sites (Table 1, Suppl. material 1)

\section{Panurginus sp. F1}

Notes: Collected from the Park County site (Table 1, Suppl. material 1)

\section{Panurginus sp. 1}

Notes: Collected from the Park County site (Table 1, Suppl. material 1) 
Protandrena (Pterosarus) innuptus (Cockerell, 1896)

Notes: Collected from the Lewis and Clark County site (Table 1, Suppl. material 1)

Agapostemon (Agapostemon) texanus Cresson, 1872

Notes: Collected from the Lewis and Clark County site (Table 1, Suppl. material 1)

Agapostemon (Agapostemon) virescens (Fabricius, 1775)

Notes: Collected from the Lewis and Clark County site (Table 1, Suppl. material 1)

Dufourea dilatipes Bohart, 1948

Notes: Collected from the Park County site (Table 1, Suppl. material 1)

Dufourea maura (Cresson, 1878)

Notes: Collected from the Lewis and Clark County, Park County and Flathead County sites (Table 1, Suppl. material 1)

Dufourea trochantera Bohart, 1948

Notes: Collected from the Lewis and Clark County site (Table 1, Suppl. material 1)

Halictus (Nealictus) farinosus Smith, 1853

Notes: Collected from the Lewis and Clark County site (Table 1, Suppl. material 1)

Halictus (Odontalictus) ligatus Say, 1837

Notes: Collected from the Lewis and Clark County site (Table 1, Suppl. material 1)

Halictus (Protohalictus) rubicundus (Christ, 1791)

Notes: Collected from the Lewis and Clark County, Park County and Flathead County sites (Table 1, Suppl. material 1)

Halictus (Seladonia) confusus Smith, 1853

Notes: Collected from the Lewis and Clark County, Park County and Flathead County sites (Table 1, Suppl. material 1), 
Halictus (Seladonia) tripartitus Cockerell, 1895

Notes: Collected from the Lewis and Clark County site (Table 1, Suppl. material 1)

Lasioglossum (Dialictus) abundipunctum Gibbs, 2010

Notes: Collected from the Lewis and Clark County site (Table 1, Suppl. material 1)

Lasioglossum (Dialictus) aff.caducum (Sandhouse, 1924)

Notes: Collected from the Lewis and Clark County site (Table 1, Suppl. material 1)

Lasioglossum (Dialictus) aff.nevadense (Crawford, 1907)

Notes: Collected from the Lewis and Clark County site (Table 1, Suppl. material 1)

Lasioglossum (Dialictus) albipenne (Robertson, 1890)

Notes: Collected from the Lewis and Clark County site (Table 1, Suppl. material 1)

Lasioglossum (Dialictus) brunneiventre (Crawford, 1907)

Notes: Collected from the Lewis and Clark County site (Table 1, Suppl. material 1)

Lasioglossum (Dialictus) ebmerellum Gibbs, 2010

Notes: Collected from the Lewis and Clark County site (Table 1, Suppl. material 1)

Lasioglossum (Dialictus) ephialtum Gibbs, 2010

Notes: Collected from the Park County and Flathead County sites (Table 1, Suppl. material 1)

Lasioglossum (Dialictus) hudsoniellum (Cockerell, 1919)

Notes: Collected from the Lewis and Clark County site (Table 1, Suppl. material 1)

Lasioglossum (Dialictus) hyalinum Crawford, 1907

Notes: Collected from the Lewis and Clark County site (Table 1, Suppl. material 1) 
Lasioglossum (Dialictus) marinense (Michener, 1936)

Notes: Collected from the Lewis and Clark County, Park County and Flathead County sites (Table 1, Suppl. material 1)

Lasioglossum (Dialictus) nevadense (Crawford, 1907)

Notes: Collected from the Lewis and Clark County site (Table 1, Suppl. material 1)

Lasioglossum (Dialictus) nigroviride (Graenicher, 1911)

Notes: Collected from the Lewis and Clark County, Park County and Flathead County sites (Table 1, Suppl. material 1)

Lasioglossum (Dialictus) aff.lilliputense Gibbs, 2010

Notes: Collected from the Lewis and Clark County site (Table 1, Suppl. material 1)

Lasioglossum (Dialictus) aff.occidentale (Crawford, 1902)

Notes: Collected from the Lewis and Clark County site (Table 1, Suppl. material 1)

Lasioglossum (Dialictus) aff.pavoninum (Ellis, 1913)

Notes: Collected from the Park County site (Table 1, Suppl. material 1)

Lasioglossum (Dialictus) obnubilum (Sandhouse, 1924)

Notes: Collected from the Park County and Flathead County sites (Table 1, Suppl. material 1)

Lasioglossum (Dialictus) occidentale (Crawford, 1902)

Notes: Collected from the Park County site (Table 1, Suppl. material 1)

Lasioglossum (Dialictus) planatum (Lovell, 1905)

Notes: Collected from the Park County site (Table 1, Suppl. material 1)

Lasioglossum (Dialictus) pruinosum (Robertson, 1892)

Notes: Collected from the Lewis and Clark County site (Table 1, Suppl. material 1) 
Lasioglossum (Dialictus) ruidosense (Cockerell, 1897)

Notes: Collected from the Lewis and Clark County and Park County sites (Table 1, Suppl. material 1)

Lasioglossum (Dialictus) sedi (Sandhouse, 1924)

Notes: Collected from the Lewis and Clark County, Park County and Flathead county sites (Table 1, Suppl. material 1)

Lasioglossum (Dialictus) semicaeruleum (Cockerell, 1895)

Notes: Collected from the Lewis and Clark County site (Table 1, Suppl. material 1)

Lasioglossum (Dialictus) sp. F17

Notes: Collected from the Park County site (Table 1, Suppl. material 1)

Lasioglossum (Dialictus) sp. F27

Notes: Collected from the Lewis and Clark County, Park County and Flathead county sites (Table 1, Suppl. material 1)

Lasioglossum (Dialictus) succinipenne (Ellis, 1913)

Notes: Collected from the Lewis and Clark County site (Table 1, Suppl. material 1)

Lasioglossum (Dialictus) tenax (Sandhouse, 1924)

Notes: Collected from the Park County site (Table 1, Suppl. material 1)

Lasioglossum (Dialictus) versatum (Robertson, 1902)

Notes: Collected from the Flathead County site (Table 1, Suppl. material 1)

Lasioglossum (Dialictus) vierecki (Crawford, 1904)

Notes: Collected from the Lewis and Clark County and Park County sites (Table 1, Suppl. material 1)

\section{Lasioglossum (Evylaeus) sp. F1}

Notes: Collected from the Lewis and Clark County, Park County and Flathead County sites (Table 1, Suppl. material 1) 


\section{Lasioglossum (Evylaeus) sp. F2}

Notes: Collected from the Lewis and Clark County and Flathead County sites (Table 1, Suppl. material 1)

\section{Lasioglossum (Evylaeus) sp. F3}

Notes: Collected from the Lewis and Clark County and Park County sites (Table 1, Suppl. material 1)

\section{Lasioglossum (Evylaeus) sp. F4}

Notes: Collected from the Flathead County site (Table 1, Suppl. material 1)

\section{Lasioglossum (Evylaeus) sp. F5}

Notes: Collected from the Lewis and Clark County, Park County and Flathead County sites (Table 1, Suppl. material 1)

\section{Lasioglossum (Evylaeus) sp. F6}

Notes: Collected from the Park County and Flathead County sites (Table 1, Suppl. material 1)

\section{Lasioglossum (Evylaeus) sp. F7}

Notes: Collected from the Lewis and Clark County site (Table 1, Suppl. material 1)

\section{Lasioglossum (Evylaeus) sp. F8}

Notes: Collected from the Lewis and Clark County site (Table 1, Suppl. material 1)

\section{Lasioglossum (Evylaeus) sp. F9}

Notes: Collected from the Lewis and Clark County site (Table 1, Suppl. material 1)

\section{Lasioglossum (Evylaeus) sp. F28}

Notes: Collected from the Lewis and Clark County and Park County sites (Table 1, Suppl. material 1) 
Lasioglossum (Lasioglossum) anhypops McGinley, 1986

Notes: Collected from the Park County and Flathead County sites (Table 1, Suppl. material 1)

Lasioglossum (Lasioglossum) egregium (Vachal, 1904)

Notes: Collected from the Lewis and Clark County and Park County sites (Table 1, Suppl. material 1)

Lasioglossum (Lasioglossum) paraforbesii McGinley, 1986

Notes: Collected from the Lewis and Clark County site (Table 1, Suppl. material 1)

Lasioglossum (Lasioglossum) sisymbrii (Cockerell, 1895)

Notes: Collected from the Lewis and Clark County and Park County sites (Table 1, Suppl. material 1)

Lasioglossum (Leuchalictus) leucozonium (Schrank, 1781)

Notes: Collected from the Lewis and Clark County site (Table 1, Suppl. material 1)

Lasioglossum (Sphecodogastra) aberrans (Crawford, 1903)

Notes: Collected from the Lewis and Clark County site (Table 1, Suppl. material 1)

Lasioglossum (Sphecodogastra) lusorium (Cresson, 1872)

Notes: Collected from the Lewis and Clark County site (Table 1, Suppl. material 1)

Anthidiellum (Loyolanthidium) notatum subsp. Robertsoni (Cockerell, 1904)

Notes: New species for Montana. Collected from the Lewis and Clark County site (Table 1, Suppl. material 1)

Anthidium (Anthidium) atrifrons Cresson, 1868

Notes: Collected from the Lewis and Clark County and Park County sites (Table 1, Suppl. material 1) 
Anthidium (Anthidium) clypeodentatum Swenk, 1914

Notes: Collected from the Lewis and Clark County site (Table 1, Suppl. material 1)

Anthidium (Anthidium) formosum Cresson, 1878

Notes: Collected from the Lewis and Clark County site (Table 1, Suppl. material 1)

Anthidium (Anthidium) mormonum Cresson, 1878

Notes: Collected from the Lewis and Clark County and Park County sites (Table 1, Suppl. material 1)

Anthidium (Anthidium) placitum Cresson, 1879

Notes: Collected from the Lewis and Clark County site (Table 1, Suppl. material 1)

Anthidium (Anthidium) tenuiflorae Cockerell, 1907

Notes: Collected from the Lewis and Clark County site (Table 1, Suppl. material 1)

Anthidium (Anthidium) utahense Swenk, 1914

Notes: Collected from the Lewis and Clark County site (Table 1, Suppl. material 1)

Ashmeadiella (Ashmeadiella) gillettei Titus, 1904

Notes: Collected from the Lewis and Clark County site (Table 1, Suppl. material 1)

Ashmeadiella (Ashmeadiella) bucconis (Say, 1837)

Notes: Collected from the Lewis and Clark County site (Table 1, Suppl. material 1)

Ashmeadiella (Ashmeadiella) cactorum (Cockerell, 1897)

Notes: Collected from the Lewis and Clark County and Park County sites (Table 1, Suppl. material 1)

Ashmeadiella (Ashmeadiella) californica (Ashmead, 1897)

Notes: Collected from the Lewis and Clark County and Park County sites (Table 1, Suppl. material 1) 
Ashmeadiella (Ashmeadiella) meliloti (Cockerell, 1897)

Notes: New species for Montana. Collected from the Lewis and Clark County site (Table 1, Suppl. material 1)

Ashmeadiella (Ashmeadiella) pronitens (Cockerell, 1906)

Notes: New species for Montana. Collected from the Park County site (Table 1, Suppl. material 1)

Chelostoma (Chelostoma) minutum Crawford, 1916

Notes: Collected from the Park County site (Table 1, Suppl. material 1)

Coelioxys (Boreocoelioxys) moesta Cresson, 1864

Notes: Collected from the Lewis and Clark County, Park County and Flathead County sites (Table 1, Suppl. material 1)

Coelioxys (Boreocoelioxys) porterae Cockerell, 1900

Notes: Collected from the Lewis and Clark County and Flathead County sites (Table 1, Suppl. material 1)

Coelioxys (Boreocoelioxys) rufitarsis Smith, 1854

Notes: Collected from the Lewis and Clark County site (Table 1, Suppl. material 1)

Coelioxys (Coelioxys) sodalis Cresson, 1878

Notes: Collected from the Lewis and Clark County site (Table 1, Suppl. material 1)

Coelioxys (Cyrtocoelioxys) modesta Smith, 1854

Notes: Collected from the Lewis and Clark County, Park County and Flathead County sites (Table 1, Suppl. material 1)

Coelioxys (Paracoelioxys) funeraria Smith, 1854

Notes: Collected from the Flathead County site (Table 1, Suppl. material 1)

Coelioxys (Synocoelioxys) alternata Say, 1837

Notes: Collected from the Lewis and Clark County site (Table 1, Suppl. material 1) 
Dianthidium (Dianthidium) cressonii (Dalla Torre, 1896)

Notes: Collected from the Lewis and Clark County site (Table 1, Suppl. material 1)

Dianthidium (Dianthidium) subparvum Swenk, 1914

Notes: Collected from the Lewis and Clark County site (Table 1, Suppl. material 1)

Dianthidium (Dianthidium) ulkei (Cresson, 1878)

Notes: Collected from the Lewis and Clark County site (Table 1, Suppl. material 1)

Dioxys productus (Cresson, 1879)

Notes: New species for Montana. Collected from the Lewis and Clark County site (Table 1, Suppl. material 1)

Heriades (Neotrypetes) carinatus Cresson, 1864

Notes: Collected from the Lewis and Clark County and Flathead County sites (Table 1, Suppl. material 1)

Heriades (Neotrypetes) cressoni Michener, 1938

Notes: Collected from the Lewis and Clark County and Park County sites (Table 1, Suppl. material 1)

Heriades (Neotrypetes) variolosa (Cresson, 1872)

Notes: Collected from the Lewis and Clark County and Flathead County sites (Table 1, Suppl. material 1)

Hoplitis (Alcidamea) albifrons subsp. argentifrons (Cresson, 1864)

Notes: Collected from the Park County site (Table 1, Suppl. material 1)

Hoplitis (Alcidamea) fulgida subsp. fulgida (Cresson, 1864)

Notes: Collected from the Lewis and Clark County, Park County and Flathead County sites (Table 1, Suppl. material 1) 
Hoplitis (Alcidamea) grinnelli (Cockerell, 1910)

Notes: Collected from the Lewis and Clark County site (Table 1, Suppl. material 1)

Hoplitis (Alcidamea) hypocrita (Cockerell, 1906)

Notes: Collected from the Lewis and Clark County site (Table 1, Suppl. material 1)

Hoplitis (Alcidamea) producta (Cresson, 1864)

Notes: Collected from the Lewis and Clark County, Park County and Flathead County sites (Table 1, Suppl. material 1)

Hoplitis (Alcidamea) truncata (Cresson, 1878)

Notes: Collected from the Lewis and Clark County site (Table 1, Suppl. material 1)

Hoplitis (Formicapis) robusta (Nylander, 1848)

Notes: Collected from the Park County site (Table 1, Suppl. material 1)

Megachile (Argyropile) parallela Smith, 1853

Notes: Collected from the Lewis and Clark County site (Table 1, Suppl. material 1)

Megachile (Chelostomoides) campanulae (Robertson, 1903)

Notes: Collected from the Lewis and Clark County site (Table 1, Suppl. material 1)

Megachile (Chelostomoides) angelarum Cockerell, 1902

Notes: Collected from the Lewis and Clark County site (Table 1, Suppl. material 1)

Megachile (Eutricharaea) apicalis Spinola, 1808

Notes: Collected from the Lewis and Clark County site (Table 1, Suppl. material 1)

Megachile (Eutricharaea) rotundata (Fabricius, 1793)

Notes: Collected from the Lewis and Clark County site (Table 1, Suppl. material 1)

Megachile (Litomegachile) brevis Say, 1837

Notes: Collected from the Lewis and Clark County site (Table 1, Suppl. material 1) 
Megachile (Litomegachile) onobrychidis Cockerell, 1905

Notes: Collected from the Lewis and Clark County site (Table 1, Suppl. material 1)

Megachile (Litomegachile) texana Cresson, 1878

Notes: Collected from the Lewis and Clark County site (Table 1, Suppl. material 1)

Megachile (Megachile) lapponica Thomson, 1872

Notes: Collected from the Lewis and Clark County, Park County and Flathead County sites (Table 1, Suppl. material 1)

Megachile (Megachile) montivaga Cresson, 1878

Notes: Collected from the Lewis and Clark County site (Table 1, Suppl. material 1)

Megachile (Megachile) relativa Cresson, 1878

Notes: Collected from the Lewis and Clark County, Park County and Flathead County sites (Table 1, Suppl. material 1)

Megachile (Megachiloides) subnigra Cresson, 1879

Notes: Collected from the Lewis and Clark County site (Table 1, Suppl. material 1)

Megachile (Megachiloides) wheeleri Mitchell, 1927

Notes: Collected from the Lewis and Clark County site (Table 1, Suppl. material 1)

Megachile (Sayapis) fidelis Cresson, 1878

Notes: Collected from the Lewis and Clark County site ((Table 1, Suppl. material 1)

Megachile (Sayapis) pugnata Say, 1837

Notes: Collected from the Lewis and Clark County, Park County and Flathead County sites (Table 1, Suppl. material 1)

Megachile (Xanthosarus) frigida Smith, 1853

Notes: Collected from the Lewis and Clark County, Park County and Flathead County sites (Table 1, Suppl. material 1) 
Megachile (Xanthosarus) gemula Cresson, 1878

Notes: Collected from the Lewis and Clark County, Park County and Flathead County sites (Table 1, Suppl. material 1)

Megachile (Xanthosarus) latimanus Say, 1823

Notes: Collected from the Lewis and Clark County site (Table 1, Suppl. material 1)

Megachile (Xanthosarus) melanophaea Smith, 1853

Notes: Collected from the Lewis and Clark County and Park County sites (Table 1, Suppl. material 1)

Megachile (Xanthosarus) perihirta Cockerell, 1898

Notes: Collected from the Lewis and Clark County, Park County and Flathead County sites (Table 1, Suppl. material 1)

Osmia (Cephalosmia) californica Cresson, 1864

Notes: Collected from the Lewis and Clark County site (Table 1, Suppl. material 1)

Osmia (Cephalosmia) marginipennis Cresson, 1878

Notes: Collected from the Lewis and Clark County site (Table 1, Suppl. material 1)

Osmia (Cephalosmia) montana subsp. montana Cresson, 1864

Notes: Collected from the Lewis and Clark County and Park County sites (Table 1, Suppl. material 1)

Osmia (Cephalosmia) subaustralis Cockerell, 1900

Notes: Collected from the Park County site (Table 1, Suppl. material 1)

Osmia (Hapsidosmia) iridis Cockerell and Titus, 1902

Notes: Collected from the Lewis and Clark County site (Table 1, Suppl. material 1)

Osmia (Helicosmia) coloradensis Cresson, 1878

Notes: Collected from the Lewis and Clark County, Park County and Flathead County sites (Table 1, Suppl. material 1) 
Osmia (Helicosmia) texana Cresson, 1872

Notes: Collected from the Lewis and Clark County site (Table 1, Suppl. material 1)

Osmia (Melanosmia) aff.albolateralis Cockerell, 1906

Notes: Collected from the Lewis and Clark County site (Table 1, Suppl. material 1)

Osmia (Melanosmia) aff.grindeliae Cockerell, 1900

Notes: Collected from the Lewis and Clark County site (Table 1, Suppl. material 1)

Osmia (Melanosmia) aff.paradisica Sandhouse, 1924

Notes: Collected from the Lewis and Clark County, Park County and Flathead County sites (Table 1, Suppl. material 1)

Osmia (Melanosmia) aff.pusilla Cresson, 1864

Notes: Collected from the Park County site (Table 1, Suppl. material 1)

Osmia (Melanosmia) albolateralis Cockerell, 1906

Notes: Collected from the Lewis and Clark County, Park County and Flathead County sites (Table 1, Suppl. material 1)

Osmia (Melanosmia) atrocyanea Cockerell, 1897

Notes: Collected from the Lewis and Clark County site (Table 1, Suppl. material 1)

Osmia (Melanosmia) brevis Cresson, 1864

Notes: Collected from the Lewis and Clark County and Park County sites (Table 1, Suppl. material 1)

Osmia (Melanosmia) bruneri Cockerell, 1897

Notes: Collected from the Lewis and Clark County site (Table 1, Suppl. material 1)

Osmia (Melanosmia) bucephala Cresson, 1864

Notes: Collected from the Lewis and Clark County, Park County and Flathead County sites (Table 1, Suppl. material 1) 
Osmia (Melanosmia) cyanella Cockerell, 189

Notes: Collected from the Flathead County site (Table 1, Suppl. material 1)

Osmia (Melanosmia) densa Cresson, 1864

Notes: Collected from the Lewis and Clark County, Park County and Flathead County sites (Table 1, Suppl. material 1)

Osmia (Melanosmia) ednae Cockerell, 1907

Notes: Collected from the Park County site (Table 1, Suppl. material 1)

Osmia (Melanosmia) grindeliae Cockerell, 1910

Notes: Collected from the Lewis and Clark County, Park County and Flathead County sites (Table 1, Suppl. material 1)

Osmia (Melanosmia) inermis (Zetterstedt, 1838)

Notes: Collected from the Lewis and Clark County, Park County and Flathead County sites (Table 1, Suppl. material 1)

Osmia (Melanosmia) integra Cresson, 1878

Notes: Collected from the Lewis and Clark County site (Table 1, Suppl. material 1)

Osmia (Melanosmia) juxta Cresson, 1864

Notes: Collected from the Lewis and Clark County, Park County and Flathead County sites (Table 1, Suppl. material 1)

Osmia (Melanosmia) kincaidii Cockerell, 1897

Notes: Collected from the Lewis and Clark County site (Table 1, Suppl. material 1)

Osmia (Melanosmia) longula Cresson, 1864

Notes: Collected from the Lewis and Clark County and Park County sites (Table 1, Suppl. material 1)

Osmia (Melanosmia) malina Cockerell, 1909

Notes: Collected from the Lewis and Clark County site (Table 1, Suppl. material 1) 
Osmia (Melanosmia) nigrifrons Cresson, 1878

Notes: Collected from the Lewis and Clark County and Park County sites (Table 1, Suppl. material 1)

Osmia (Melanosmia) nigriventris (Zetterstedt, 1838)

Notes: Collected from the Park County site (Table 1, Suppl. material 1)

Osmia (Melanosmia) odontogaster gr.sp.1

Notes: Collected from the Lewis and Clark County and Park County sites (Table 1, Suppl. material 1)

Osmia (Melanosmia) odontogaster gr.sp.2

Notes: Collected from the Park County site (Table 1, Suppl. material 1)

Osmia (Melanosmia) paradisica Sandhouse, 1924

Notes: Collected from the Park County site (Table 1, Suppl. material 1)

Osmia (Melanosmia) pentstemonis Cockerell, 1906

Notes: Collected from the Lewis and Clark County, Park County and Flathead County sites (Table 1, Suppl. material 1)

Osmia (Melanosmia) phaceliae Cockerell, 1907

Notes: Collected from the Lewis and Clark County, Park County and Flathead County sites (Table 1, Suppl. material 1)

Osmia (Melanosmia) physariae Cockerell, 1907

Notes: Collected from the Park County site (Table 1, Suppl. material 1)

Osmia (Melanosmia) pikei Cockerell, 1907

Notes: Collected from the Park County site (Table 1, Suppl. material 1)

Osmia (Melanosmia) proxima Cresson, 1864

Notes: Collected from the Park County site (Table 1, Suppl. material 1) 


\section{Osmia (Melanosmia) pusilla Cresson, 1864}

Notes: Collected from the Lewis and Clark County, Park County and Flathead County sites (Table 1, Suppl. material 1)

Osmia (Melanosmia) sculleni Sandhouse, 1939

Notes: Collected from the Park County site (Table 1, Suppl. material 1)

Osmia (Melanosmia) simillima Smith, 1853

Notes: Collected from the Lewis and Clark County site (Table 1, Suppl. material 1)

Osmia (Melanosmia) sp.3

Notes: Collected from the Flathead County site (Table 1, Suppl. material 1)

\section{Osmia (Melanosmia) sp.9}

Notes: Collected from the Lewis and Clark County site (Table 1, Suppl. material 1)

Osmia (Melanosmia) tersula Cockerell, 1912

Notes: Collected from the Park County site (Table 1, Suppl. material 1)

Osmia (Melanosmia) trevoris Cockerell, 1897

Notes: Collected from the Lewis and Clark County site (Table 1, Suppl. material 1)

Osmia (Melanosmia) tristella Cockerell, 1897

Notes: Collected from the Lewis and Clark County, Park County and Flathead County sites (Table 1, Suppl. material 1)

Osmia (Osmia) lignaria subsp. propinqua Cresson, 1864

Notes: Collected from the Lewis and Clark County and Park County sites (Table 1, Suppl. material 1)

Stelis (Stelis) aff. permaculata Cockerell, 1898

Notes: Collected from the Lewis and Clark County site (Table 1, Suppl. material 1) 
Stelis (Stelis) calliphorina (Cockerell, 1911)

Notes: Collected from the Lewis and Clark County site (Table 1, Suppl. material 1)

Stelis (Stelis) callura Cockerell, 1925

Notes: Collected from the Lewis and Clark County site (Table 1, Suppl. material 1)

Stelis (Stelis) carnifex Cockerell, 1911

Notes: Collected from the Lewis and Clark County and Park County sites (Table 1, Suppl. material 1)

\section{Stelis (Stelis) foederalis gr.sp.2}

Notes: Collected from the Lewis and Clark County site (Table 1, Suppl. material 1)

\section{Stelis (Stelis) foederalis gr.sp.6}

Notes: Collected from the Lewis and Clark County and Flathead County sites (Table 1, Suppl. material 1)

\section{Stelis (Stelis) foederalis gr.sp.7}

Notes: Collected from the Park County site (Table 1, Suppl. material 1)

\section{Stelis (Stelis) foederalis gr.sp.8}

Notes: Collected from the Park County site (Table 1, Suppl. material 1)

\section{Stelis (Stelis) montana Cresson, 1864}

Notes: Collected from the Lewis and Clark County, Park County and Flathead County sites (Table 1, Suppl. material 1)

Stelis (Stelis) monticola Cresson, 1878

Notes: Collected from the Lewis and Clark County and Park County sites (Table 1, Suppl. material 1)

Stelis (Stelis) nitida Cresson, 1878

Notes: Collected from the Park County site (Table 1, Suppl. material 1) 
Stelis (Stelis) permaculata Cockerell, 1898

Notes: Collected from the Lewis and Clark County site (Table 1, Suppl. material 1)

Anthophora (Clisodon) terminalis Cresson, 1869

Notes: Collected from the Lewis and Clark County and Park County sites (Table 1, Suppl. material 1)

Anthophora (Lophanthophora) pacifica Cresson, 1878

Notes: Collected from the Lewis and Clark County site (Table 1, Suppl. material 1)

Anthophora (Lophanthophora) ursina Cresson, 1869

Notes: Collected from the Lewis and Clark County site (Table 1, Suppl. material 1)

Anthophora (Melea) bomboides Kirby, 1838

Notes: Collected from the Lewis and Clark County site (Table 1, Suppl. material 1)

Anthophora (Mystacanthophora) urbana Cresson, 1878

Notes: Collected from the Lewis and Clark County site (Table 1, Suppl. material 1)

Apis mellifera Linnaeus, 1758

Notes: Collected from the Lewis and Clark County and Park County sites (Table 1, Suppl. material 1)

Bombus (Bombus) occidentalis Greene, 1858

Notes: Collected from the Park County and Flathead County sites (Table 1, Suppl. material 1)

Bombus (Cullumanobombus) griseocollis (De Geer, 1773)

Notes: Collected from the Lewis and Clark County site (Table 1, Suppl. material 1)

Bombus (Cullumanobombus) rufocinctus Cresson, 1863

Notes: Collected from the Lewis and Clark County, Park County and Flathead County sites (Table 1, Suppl. material 1) 
Bombus (Psithyrus) flavidus Eversmann, 1852

Notes: Collected from the Park County and Flathead County sites (Table 1, Suppl. material 1)

Bombus (Psithyrus) insularis (Smith, 1861)

Notes: Collected from the Lewis and Clark County, Park County and Flathead County sites (Table 1, Suppl. material 1)

Bombus (Psithyrus) suckleyi Greene, 1860

Notes: Collected from the Flathead County site (Table 1, Suppl. material 1)

Bombus (Pyrobombus) bifarius Cresson, 1878

Notes: Collected from the Lewis and Clark County, Park County and Flathead County sites (Table 1, Suppl. material 1)

Bombus (Pyrobombus) centralis Cresson, 1864

Notes: Collected from the Lewis and Clark County, Park County and Flathead County sites (Table 1, Suppl. material 1)

Bombus (Pyrobombus) flavifrons Cresson, 1863

Notes: Collected from the Lewis and Clark County, Park County and Flathead County sites (Table 1, Suppl. material 1)

Bombus (Pyrobombus) huntii Greene, 1860

Notes: Collected from the Lewis and Clark County and Park County sites (Table 1, Suppl. material 1)

Bombus (Pyrobombus) melanopygus Nylander, 1848

Notes: Collected from the Park County and Flathead County sites (Table 1, Suppl. material 1)

Bombus (Pyrobombus) mixtus Cresson, 1878

Notes: Collected from the Park County and Flathead County sites (Table 1, Suppl. material 1) 
Bombus (Pyrobombus) sitkensis Nylander, 1848

Notes: Collected from the Flathead County site (Table 1, Suppl. material 1)

Bombus (Pyrobombus) vagans Smith, 1854

Notes: Collected from the Flathead County site (Table 1, Suppl. material 1)

Bombus (Subterraneobombus) appositus Cresson, 1878

Notes: Collected from the Lewis and Clark County, Park County and Flathead County sites (Table 1, Suppl. material 1)

Bombus (Subterraneobombus) borealis Kirby, 1837

Notes: Collected from the Lewis and Clark County site (Table 1, Suppl. material 1)

Bombus (Thoracobombus) californicus Smith, 1854

Notes: Collected from the Flathead County site (Table 1, Suppl. material 1)

Bombus (Thoracobombus) fervidus (Fabricius, 1798)

Notes: Collected from the Lewis and Clark County and Park County sites (Table 1, Suppl. material 1)

Ceratina (Zadontomerus) nanula Cockerell, 1897

Notes: Collected from the Lewis and Clark County, Park County and Flathead County sites (Table 1, Suppl. material 1)

Ceratina (Zadontomerus) neomexicana Cockerell, 1901

Notes: Collected from the Lewis and Clark County site (Table 1, Suppl. material 1)

Diadasia (Coquillettapis) diminuta (Cresson, 1878)

Notes: Collected from the Lewis and Clark County site (Table 1, Suppl. material 1)

\section{Epeolus sp.}

Notes: Collected from the Lewis and Clark County site (Table 1, Suppl. material 1) 
Eucera (Synhalonia) edwardsii (Cresson, 1878)

Notes: Collected from the Lewis and Clark County site (Table 1, Suppl. material 1)

Eucera (Synhalonia) frater (Cresson, 1878)

Notes: Collected from the Lewis and Clark County site (Table 1, Suppl. material 1)

Eucera (Synhalonia) fulvitarsis (Cresson, 1878)

Notes: Collected from the Lewis and Clark County site (Table 1, Suppl. material 1)

Melecta (Melecta) pacifica subsp. fulvida Cresson, 1878

Notes: Collected from the Lewis and Clark County site (Table 1, Suppl. material 1)

Melecta (Melecta) separata Cresson, 1879

Notes: Collected from the Lewis and Clark County site (Table 1, Suppl. material 1)

Melissodes (Eumelissodes) confusa Cresson, 1878

Notes: Collected from the Lewis and Clark County site (Table 1, Suppl. material 1)

Melissodes (Eumelissodes) coreopsis Robertson, 1905

Notes: Collected from the Lewis and Clark County site (Table 1, Suppl. material 1)

Melissodes (Eumelissodes) hymenoxidis Cockerell, 1906

Notes: Collected from the Lewis and Clark County site (Table 1, Suppl. material 1)

Melissodes (Eumelissodes) microstictus Cockerell, 1905

Notes: Collected from the Lewis and Clark County and Park County sites (Table 1, Suppl. material 1)

Melissodes (Eumelissodes) utahensis LaBerge, 1961

Notes: Collected from the Lewis and Clark County site (Table 1, Suppl. material 1)

Melissodes (Heliomelissodes) rivalis Cresson, 1872

Notes: Collected from the Lewis and Clark County site (Table 1, Suppl. material 1) 


\section{Melissodes sp. F1}

Notes: Collected from the Lewis and Clark County site (Table 1, Suppl. material 1)

\section{Melissodes sp. F2}

Notes: Collected from the Lewis and Clark County site (Table 1, Suppl. material 1)

\section{Melissodes unk1}

Notes: Collected from the Lewis and Clark County site (Table 1, Suppl. material 1)

\section{Nomada edwardsii Cresson, 1878}

Notes: Collected from the Lewis and Clark County site (Table 1, Suppl. material 1)

\section{Nomada sp. F1}

Notes: Collected from the Lewis and Clark County site (Table 1, Suppl. material 1)

\section{Nomada sp. F2}

Notes: Collected from the Lewis and Clark County site (Table 1, Suppl. material 1)

\section{Nomada sp. F3}

Notes: Collected from the Lewis and Clark County and Park County sites (Table 1, Suppl. material 1)

\section{Nomada sp. F4}

Notes: Collected from the Lewis and Clark County site (Table 1, Suppl. material 1)

\section{Nomada sp. F5}

Notes: Collected from the Lewis and Clark County site (Table 1, Suppl. material 1)

\section{Nomada sp. F6}

Notes: Collected from the Park County site (Table 1, Suppl. material 1)

\section{Nomada sp. F7}

Notes: Collected from the Lewis and Clark County site (Table 1, Suppl. material 1) 


\section{Nomada sp. F8}

Notes: Collected from the Flathead County site (Table 1, Suppl. material 1)

\section{Triepeolus paenepectoralis Viereck, 1905}

Notes: Collected from the Lewis and Clark County site (Table 1, Suppl. material 1)

\section{Analysis}

We collected 8011 bee specimens representing 281 species and morphospecies in 32 genera and five families between 2013 and 2016. Following are the total number of specimens by family (to avoid inflating species richness, we did not include male morphospecies in species counts because female morphospecies may have been the same species): Colletidae: 357 specimens, 2 genera, 17 species; Andrenidae: 395 specimens, 3 genera, 44 species and morphospecies; Halictidae: 1251 specimens, 4 genera, 55 species and morphospecies; Megachilidae: 2920 specimens, 12 genera, 113 species and morphospecies; Apidae: 3088 specimens, 11 genera, 52 species and morphospecies.

Though resources did not allow for a comprehensive literature search to assess new state records for all the species on this checklist, an exploratory search for 25 of the species (in no particular order) revealed no previously published records in Montana for Andrena saccata Viereck; Anthidiellum notatum robertsoni (Cockerell); Ashmeadiella meliloti (Cockerell); Ashmeadiella pronitens (Cockerell); Colletes lutzi lutzi Timberlake; and Dioxys productus (Cresson). In addition, Dolan et al. (2017) reported a specimen of Bombus borealis Kirby from this study to be a first Montana state record. In effect, this brings the number of known bee species in Montana up from 366 (Kuhlman and Burrows 2017) to at least 372 , and indicates a clear need for more extensive bee surveys in the state.

\section{Discussion}

Because Montana spans a large area of diverse topography, landscape and climate (Dolan et al. 2017), species groups are likely to vary among different locations. For instance, compared with a checklist of bees from a similar montane habitat in Montana (Kuhlman and Burrows 2017), there was some overlap among species, with 121 species (not including morphospecies) in common with our list, but also some variability, with 126 species unique to our study. When compared to an unpublished study on bees associated with native flower strips around agricultural fields in the Gallatin Valley, Montana (C.M. Delphia pers. com.), the species suites included 117 species in common and 130 unique to our study. We expect that future biosurvey efforts will reveal hundreds of species not yet listed in Montana. 
There is growing evidence of declines in wild bee species diversity (Winfree et al. 2009, Winfree 2010, Potts et al. 2010, Burkle et al. 2013, Goulson et al. 2015, Woodcock et al. 2016, Koh et al. 2015). In order to determine whether bee declines are occurring, baseline data or repeated monitoring surveys are required. The lack of comprehensive surveys or monitoring of native bee populations across Montana has resulted in a lack of species lists for the state as well as difficulty in tracking population, species, and community trends. This checklist adds to the basic understanding of native bee fauna, and we hope it will stimulate further research in this important field.

\section{References}

- $\quad$ Ascher J, Pickering J (2016) Discover life bee species guide and world checklist (Hymenoptera: Apoidea: Anthophila). Discoverlife.org.

- $\quad$ Baker J (1975) Taxonomy of five nearctic subgenera of Coelioxys (Hymenoptera: Megachilidae). University of Kansas Science Bulletin 50 (12): 649-730.

- Bouseman J, LaBerge W (1978) A Revision of the bees of the genus Andrena of the Western Hemisphere. Part IX. Subgenus Melandrena . Transactions of the American Entomological Society 104 (3/4): 275-389.

- Brumley R (1965) A revision of the bee genus Epeolus of western America north of Mexico. Utah State University, Logan.

- $\quad$ Burkle L, Marlin J, Knight T (2013) Plant-pollinator interactions over 120 years: loss of species, co-occurrence, and function. Science 29 (339): 1611-1615. https://

doi.org/10.1126/science.1232728

- $\quad$ Burkle L, Myers J, Belote RT (2015) Wildfire disturbance and productivity as drivers of plant species diversity across spatial scales. Ecosphere 6 (10): 1-14. https:// doi.org/10.1890/es15-00438.1

- Council, Natural Resource (2007) Status of pollinators in North America. National Academies Press

- Daly H (1973) Bees in the genus Ceratina in America north of Mexico. University of California Publications in Entomology 74: 1-117.

- DeSilva N (2012) Revision of the cleptoparasitic bee genus Coelioxys (Hymenoptera: Megachlidae) in Canada. York University, Toronto, Ontario, Canada.

- Dolan A, Delphia C, O'Neill K, Ivie M (2017) Bumble bees (Hymenoptera: Apidae) of Montana. Annals of the Entomological Society of America 110 (2): 129-144.

- Donovan B (1977) A revision of North American bees of the subgenus Cnemidandrena (Hymenoptera, Andrenidae). University of California Publications in Entomology 81: 1-107.

- $\quad$ Dumesh S, Sheffield CS (2012) Bees of the genus Dufourea Lepeletier (Hymenoptera: Halictidae: Rophitinae) of Canada. Canadian Journal of Arthropod Identification 20: 1-36.

- Gibbs J (2010) Revision of the metallic species of Lasioglossum (Dialictus) in Canada (Hymenoptera, Halictidae, Halictini). Zootaxa 2591: 1-382.

- Gonzalez V, Griswold T (2013) Wool carder bees of the genus Anthidium in the Western Hemisphere (Hymenoptera: Megachilidae, Anthidiini) with a phylogenetic analysis of the 
subgenera. Zoological Journal of the Linnean Society 168: 221-425. https:// doi.org/10.1111/zoj.12017

- Goulson D, Nicholls E, Botias C, Rotheray E (2015) Bee declines driven by combined stress from parasites, pesticides, and lack of flowers. Science 347 (6229): 1255957. https://doi.org/10.1126/science.1255957

- $\quad$ Green R, Balmford A, Crane P, Mace G, Reynolds J, Turner R (2005) A Framework for improved monitoring of biodiversity: Responses to the World Summit on Sustainable Development. Conservation Biology 19 (1): 56-65. https://doi.org/10.1111/ j.1523-1739.2005.00289.x

- Grigarick A, Stange L (1968) Pollen-collecting bees of the Anthidiini of California (Hymenoptera: Megachilidae). Bulletin of the California Insect Survey 9: 1-113.

- Hurd P, Linsley E (1951) The melectine bees of California (Hymenoptera: Anthophoridae). Bulletin of the California Insect Survey 1: 119-135.

- $\quad$ Hurd P, Michener C (1955) The megachiline bees of California (Hymenoptera: Megachilidae). Bulletin of the California Insect Survey 3: 1-247.

- Hurd P (1958) American bees of the genus Dioxys Lepeletier and Serville (Hymenoptera: Megachilidae). University of California Publications in Entomology 14 (4): 275-302.

- $\quad$ Kincaid T, Olsen A (2011) spsurvey: Spatial Survey Design and Analysis. R package. 3.4.

- $\quad$ Koch J, Strange J, Williams P (2012) Bumble bees of the western United States. US Forest Service, $143 \mathrm{pp}$.

- $\quad$ Koh I, Lonsdorf E, Williams N, Brittain C, Isaacs R, Gibbs J, Ricketts T (2015) Modeling the status, trends, and impacts of wild bee abundance in the United States.

Proceedings of the National Academy of Sciences 113 (1): 140-145. https:// doi.org/10.1073/pnas.1517685113

- Kuhlman M, Burrows S (2017) Checklist of bees (Apoidea) from a private conservation property in west-central Montana. Biodiversity Data Journal 5: e11506. https:// doi.org/10.3897/bdj.5.e11506

- $\quad$ LaBerge W (1956a) A revision of the bees of the genus Melissodes in North and Central America. Part I (Hymenoptera, Apidae). The University of Kansas Science Bulletin 37: 911-1194. https://doi.org/10.5962/bhl.part.24549

- LaBerge W (1956b) A revision of the bees of the genus Melissodes in North and Central America: Part II (Hymenoptera, Apidae). University of Kansas Science Bulletin 38: 533-578.

- LaBerge W (1961) A revision of the bees of the genus Melissodes in North and Central America: Part III (Hymenoptera, Apidae). University of Kansas Science Bulletin 42: 283-663. https://doi.org/10.5962/bhl.part.9821

- $\quad$ LaBerge W (1969) A revision of the bees of the genus Andrena of the Western Hemisphere. Part II. Plastandrena, Aporandrena, Charitandrena. Transactions of the American Entomological Society 1890 (95): 1-47.

- LaBerge W, Ribble D (1972) A revision of the bees of the genus Andrena of the Western Hemisphere. Part V. Gonandrena, Geissandrena, Parandrena, Pelicandrena. Transactions of the American Entomological Society 1890 (98): 271-358.

- LaBerge W (1973) A revision of the bees of the genus Andrena of the Western Hemisphere. Part VI. Subgenus Trachandrena. Transactions of the American Entomological Society 1890 (99): 235-371. 
- LaBerge W, Ribble D (1975) A revision of the bees of the genus Andrena of the Western Hemisphere. Part VII. Subgenus Euandrena. Transactions of the American Entomological Society 1890 (101): 371-446.

- LaBerge W (1977) A revision of the bees of the genus Andrena of the Western Hemisphere. Part VIII. Subgenera Thysandrena, Dasyandrena, Psammandrena, Rhacandrena, Euandrena, Oxyandrena. Transactions of the American Entomological Society 1890 (103): 1-143.

- LaBerge W (1980) A revision of the bees of the genus Andrenaof the Western Hemisphere. Part X. SubgenusAndrena . Transactions of the American Entomological Society 1890 (106): 395-525.

- LaBerge W (1985) A revision of the bees of the genus Andrena of the Western Hemisphere. Part XI. Minor subgenera and Subgeneric Key. Transactions of the American Entomological Society 1890 (111): 441-567.

- LaBerge W (1986) A revision of the bees of the genus Andrena of the Western Hemisphere. Part XII. Subgenera Leucandrena, Ptilandrena, Scoliandrena and Melandrena . Transactions of the American Entomological Society 1890 (112): 191-248.

- Lengyel S, Kobler A, Kutnar L, Framstad E, Henry P, Babij V, Gruber B, Schmeller D, Henle K (2008) A review and a framework for the integration of biodiversity monitoring at the habitat level. Biodiversity and Conservation 17 (14): 3341-3356. https:// doi.org/10.1007/s10531-008-9359-7

- Losos J, Arnold S, Bejerano G, Brodie ED, Hibbett D, Hoekstra H, Mindell D, Monteiro A, Moritz C, Orr HA, Petrov D, Renner S, Ricklefs R, Soltis P, Turner T (2013) Evolutionary Biology for the 21st Century. PLoS Biology 11 (1): e1001466. https:// doi.org/10.1371/journal.pbio.1001466

- McGinley R (1986) Studies of Halictinae (Apoidea: Halictidae), I: Revision of New World Lasioglossum Curtis. Smithsonian Contributions to Zoology 429: 1-294. https:// doi.org/10.5479/si.00810282.429

- McGinley R (2003) Studies of Halictinae (Apoidea: Halictidae) II: Revision of Sphecodogastra, floral specialists of Onagraceae. Smithsonian Contributions to Zoology 168: 221-425.

- Michener C (1938) American bees of the genus Chelostoma . Pan-Pacific Entomologist 14: 36-46.

- Michener C (1947) A revision of the American species of Hoplitis (Hymenoptera, Megachilidae). Bulletin of the American Museum of Natural History 89: 257-318.

- $\quad$ Neff J, Simpson B (1993) Bees, pollination systems and plant diversity. CAB International, Wallingford, UK.

- $\quad$ Potts S, Biesmeijer J, Kremen C, Neumann P, Schweiger O, Kunin W (2010) Global pollinator declines: trends, impacts and drivers. Trends in Ecology \& Evolution 25 (6):

345-353. https://doi.org/10.1016/j.tree.2010.01.007

- $\quad$ Ribble D (1968) A revison of the bees of the genus Andrena: Micandrena Ashmead and Derandrena, new subgenus (Hymenoptera: Apoidea). Bulletin of the Nebraska State Museum 8 (5): 237-394.

- Ribble D (1974) A revision of the bees of the genus Andrena of the western hemisphere subgenus Scaphandrena . Transactions of the American Entomological Society 100: 101-189.

- $\quad$ Rightmyer M (2008) A review of the cleptoparasitic bee genus Triepeolus (Hymenoptera: Apidae). Part I. Zootaxa 1710: 1-170. 
- $\quad$ Rightmyer M, Griswold T, Arduser M (2010) A review of the non-metallic Osmia (Melanosmia) found in North America, with additional notes on palearctic Melanosmia (Hymenoptera, Megachilidae). ZooKeys 60: 37-77. https://doi.org/10.3897/ zookeys.60.484

- $\quad$ Roberts R (1973a) Bees of Northwestern America: Halictus (Hymenoptera: Halictidae). Corvallis Agricultural Experiment Station, Oregon State University, Corvallis, 1-23 pp.

- $\quad$ Roberts R (1973b) Bees of Northwestern America: Agapostemon (Hymenoptera: Halictidae). Corvallis Agricultural Experiment Station, Oregon State University, Corvallis, 1-23 pp.

- $\quad$ Sandhouse G (1939) North American bees of the genus Osmia (Hymenoptera: Apoidea). The Entomological Society of Washington, Washington, D.C, $167 \mathrm{pp}$.

- Sheffield C, Ratti C, Packer L, Griswold T (2011) Leaf-cutter and mason bees of the genus Megachile Latreille (Hymenoptera: Megachilidae) in Canada and Alaska. Canadian Journal of Arthropod Identification 18: 1-107.

- Sipes S (2001) Phylogenetic relationships, taxonomy, and evolution of host choice in Diadasia (Hymenoptera: Apoidea). Utah State University, 58-151 pp.

- $\quad$ Snelling RR (1966a) Studies on North American bees of the genus Hylaeus. 3. The Nearctic subgenera (Hymenoptera: Colletidae). Bulletin of the Southern California Academy of Sciences 65: 164-175.

- $\quad$ Snelling RR (1966b) Studies on North American bees of the genus Hylaeus. 1. Distribution of the western species of the subgenus Prosopis with descriptions of new forms (Hymenoptera: Colletidae). Contributions in Science, Los Angeles County Museum 98: 1-18.

- Snelling RR (1970) Studies on North American bees of the genus Hylaeus. 5. The subgenera Hylaeus, s. str. and Paraprosopis (Hymenoptera: Colletidae). Contributions in Science 180: 1-59.

- Stephen W (1954) A revision of the bee genus Colletes in America north of Mexico (Hymenoptera, Colletidae). University of Kansas Science Bulletin 36: 149-527.

- Taylor J (2012) Status and trends of land change in the Western United States 1973 to 2000. Chapter 7: Northern Rockies Ecoregion. US Geological Survey

- Thorp R (1969) Systematics and ecology of bees of the subgenus Diandrena (Hymenoptera, Apidae). Bulletin of the California Insect Survey 23: 1-79.

- Thorp RW, Horning DS, Lorry LD (1983) Bumble bees and cuckoo bumble bees of California (Hymenoptera, Apidae). Bulletin of the California Insect Survey 23: 1-79.

- Timberlake P (1969) A contribution to the systematics of North American species of Synhalonia (Hymenoptera, Apoidea). University of California Publications in Entomology 57: 1-7.

- Timberlake P (1976) Revision of the North American bees of the genus Protandrena Cockerell (Hymenoptera: Apoidea). Transactions of the American Entomological Society 1890 (102): 133-227.

- Western Regional Climate Center (2016) Cooperative Climatological Data. http:// www.wrcc.dri.edu/. Accessed on: 2016-6-19.

- Williams P, Thorp R, Richardson L, Colla S (2014) Bumble Bees of North America: An Identification Guide. Princeton University Press, 208 pp.

- Winfree R, Aguilar R, Vázquez D, LeBuhn G, Aizen M (2009) A meta-analysis of bees' responses to anthropogenic disturbance. Ecology 90 (8): 2068-2076. https:// doi.org/10.1890/08-1245.1 
- Winfree R (2010) The conservation and restoration of wild bees. Annals of the New York Academy of Sciences 1195 (1): 169-197. https://doi.org/10.1111/ j.1749-6632.2010.05449.x

- Woodcock B, Isaac N, Bullock J, Roy D, Garthwaite D, Crowe A, Pywell R (2016) Impacts of neonicotinoid use on long-term population changes in wild bees in England. Nature Communications 7: 12459. https://doi.org/10.1038/ncomms12459

\section{Supplementary material}

\section{Suppl. material 1: Supplementary Table1 doi}

Authors: Elizabeth G. Reese, Laura A. Burkle, Casey M. Delphia, Terry Griswold Data type: Species Collection Dates

Filename: Supplementary Table1.pdf - Download file (117.95 kb) 